\title{
PENGARUH PROMOSI DAN KUALITAS PRODUK TERHADAP KEPUTUSAN PEMBELIAN PADA KONSUMEN KERAJINAN TENUN GEDONGAN DI DESA PRINGGASELA SELATAN LOMBOK TIMUR
}

\author{
Masbullah dan Salmi Yuniar Bahri \\ Program Studi Administrasi Publik STIA Muhammadiyah Selong \\ Email: masbullah88@gmail.com dan salmijuniar@gmail.com
}

\begin{tabular}{l}
\multicolumn{1}{c}{ Artikelinfo } \\
\hline Artikel history: \\
Received : 07-09-2020 \\
Revised : 15-09-2020 \\
Approved : 20-09-2020
\end{tabular}

Kata Kunci:

Promosi, Kualitas Produk, Keputusan Pembelian, Nine Penenun

\begin{abstract}
$\overline{\text { Abstrak: Dalam penelitian ini tujuan yang ingin dicapai yaitu untuk }}$ mengetahui Pengaruh promosi dan kualitas produk terhadap keputusan pembelian pada konsumen kerajinan tenun gedongan di desa pringgasela selatan lombok timur (studi pada kelompok nine penenun (KNP) desa pringgasela selatan). Metode teknik analisis data yang digunakan adalah menguji reliabilitas dan validitas, menguji asumsi klasik, regresi linier berganda dan uji hipotesis dengan uji $F$ dan uji $T$. Menguji reliabilitas dan validitas dilakukan terhadap hasil jawaban dari responden dan menggunakan metode penghitungan statistik. Menguji asumsi klasik yang dilakukan melalui beberapa tahapan yaitu menguji multikolinearitas, menguji normalitas dan menguji heteroskedastisitas. Regresi linier berganda untuk menggambarkan model hubungan antara variabel bebas dan variabel terikat. Menguji $F$ sering disebut uji simultan, yang digunakan untuk menguji apakah variabel independen yang digunakan dalam model dapat menjelaskan perubahan nilai variabel dependen atau tidak. Menguji T digunakan untuk mengetahui pengaruh dari masing-masing variabel independen yang terdiri dari promosi dan kualitas produk terhadap keputusan pembelian pada konsumen kerajinan tenun gedongan di desa pringgasela selatan lombok timur (studi pada kelompok nine penenun $(K N P)$ desa pringgasela selatan). Hasil dalam penelitian ini menunjukkan bahwa pengaruh promosi dan kualitas produk terhadap keputusan pembelian pada konsumen kerajinan tenun gedongan di desa pringgasela selatan lombok timur, studi pada kelompok nine penenun (KNP) desa pringgasela selatan memiliki pengaruh yang signifikan terhadap keputusan pembelian kerajinan kain tenun di kelompok nine penenun (KNP) desa pringgasela selatan Lombok Timur.
\end{abstract}

koresponden author : Masbullah Email:masbullah88@gmail.com artikel dengan akses terbuka dibawah lisensi

CC BY SA

2020 


\section{PENDAHULUAN}

Di era globalisasi saat ini tingkat persaingan dunia usaha dan industri di Indonesia semakin ketat dan kompleks, karena setiap dunia usaha senantiasa berusaha untuk dapat meningkatkan pangsa pasar dan meraih konsumen dan pelanggan baru sebanyak-banyaknya. Perusahaan harus dapat menentukan mekanisme serta strategi pemasaran yang tepat, cepat, dan terencana agar usaha yang digeluti dapat bertahan dan memenangi persaingan di pasaran, sehingga visi dan misi dari perusahaan tersebut dapat tercapai sesuai dengan planning yang telah disusun. Pada prinsipnya semakin banyak pesaingan maka akan semakin banyak pula berbagai macam pilihan bagi konsumen untuk dapat memilih produk yang sesuai dengan harapan dan seleranya. Sehingga konsekuensi dan resiko dari perubahan tersebut adalah konsumen menjadi lebih cermat dan cerdas dalam menghadapi setiap produk yang diluncurkan oleh dunai usaha ke pasaran.

Persaingan yang sangat ketat tersebut dalam merebut perhatian konsumen mengharuskan para pengusaha dalam produksinya untuk dapat merencanakan dan merancang promosi yang inovatif, kreatif, persuasif dan meningkatkan kualitas produk sebagus mungkin dan berkualitas. Padas saat volume promosi meningkat tajam, maka disana juga para konsumen akan menjadi lebih teliti dan selektif dalam melihat terhadap suatu produk atau merek yang dikeluarkan oleh pengusaha. Hal tersebut dapat disebabkan karena faktor konsumen sasaran (audience) yang memiliki keterbatasan daya ingat untuk mengingat secara keseluruhan dari promosi yang dilakukan oleh pengusaha kepada calon konsumen. Dalam hal ini pomosi merupakan bentuk persuasi langsung melalui penggunaan berbagai insentif yang dapat diatur untuk meransang pembelian produk dengan segera dan atau meningkatkan jumlah yang dibeli pelanggan serta membuat konsumen puas sehingga melakukan pembelian kembali (Malau, 2017).

Melihat perkembangan dunia pariwisata di Provinsi Nusa Tenggara Barat (NTB) saat ini menunjukkan kemajuan yang sangat signifikan, kemajuan di dunia pariwisata tersebut tidak lepas dengan adanya peningkatan dan kualitas dari infrastruktur sebagai pendukung yang telah memadai seperti adanya Lombok International Airport (LIA) di tanak awu Praya Lombok Tengah, Pelabuhan penyeberangan yang semakin memadai dan bagus, jalan raya dan akses jalan Baypass dari Kota Mataram dan serta banyaknya daya tarik wisata alam berupa pantai, air tenjun dan wisata alam lainnya maupun seni dan budaya yang beraneka ragam, diresmikannya KEK Mandalika tersebut menjadikan Provinsi Nusa Tenggara Barat (NTB) menjadi salah satu daya tarim dan menjadi primadona baru sebagai destinasi pariwisata pilihan utama di Indonesia. Di samping jumlah wisatawan yang semakin meningkat tajam dari waktu ke waktu, para wisatawan tidak lagi terfokus hanya ingin santai dan menikmati $3 \mathrm{~S}$ (sun-sea and sand), namun lebih menikmati produk atau kreasi budaya (culture), peninggalan sejarah (heritage) dan alam (nature) dari suatu daerah atau negara.

Desa Pringgasela Selatan Lombok Timur merupakan desa yang kaya akan sumber daya yang cukup bagus untuk dikembangkan, terutama sumber daya tenun gedongan yang merupakan salah satu desa wisata kerajinan tenun yang ada lama di Lombok Timur. Desa Pringgasela Selatan adalah nama sebuah desa kecil yang sangat indah dan merupakan salah satu pusat kerajinan tenun tradisional yang letaknya di Desa Pringgasela Selatan Kecamatan Pringgasela Kabupaten Lombok Timur, Nusa Tenggara Barat. Tenun gedongan merupakan warisan turun temurun yang terus dikembangkan sampai saat ini . Hal ini disebabkan karena kondisi masyarakat yang sampai saat ini masih tetap mempertahankan warisan budaya 
sebagai baktinya kepada nenek moyang mereka. Selain sebagai warisan budaya, tenun gedongan juga sebagai sumber mata pencaharian masyarakat Desa Pringgasela khususnya Desa Pringgasela Selatan.

Lokasi Desa Pringgasela Selatan ini sekitar $50 \mathrm{Km}$ dari kota Mataram atau sekitar 1 Jam perjalanan, dan sekitar $20 \mathrm{Km}$ dari kota Selong atau 5 menit perjalanan dengan menggunakan kendaraan pribadi atau taksi. Sebagian besar perempuan yang ada di Desa Pringgasela Selatan ini bekerja sebagai penenun.

Desa Pringgasela Selatan memiliki cara untuk menjaga dan melestarikan budaya dan tenun tradisional yang diwarisi oleh nenek moyang mereka maka para perempuan di Desa Pringgasela Selatan ini diwajibkan untuk belajar menenun, bahkan sejak masih usia anakanak para orang tua mereka telah mewariskan keterampilannya dan mengajarkan kepada anak-anak perempuan mereka menenun dengan motif awal atau motif dasar yang sangat sederhana untuk lebih mudah dipahami dan dipelajari oleh anak-anak mereka bagaimana cara menenun yang baik dan benar untuk mendapatkan kualitas hasil tenunan yang baik nantinya.Pekerjaan menenun di Pringgasela Selatan dilakukan di teras depan, dan kebiasaan ini masih mereka lakukan sampai saat ini.

Berkelompok merupakan wadah yang bisa mempermudah untuk menjalankan suatu usaha dan mendapatkan jaringan untuk pemasaran produk. Tidak lama para penenun berinisiatif untuk pembentuk kepengurusan suatu kelompok usaha. Pada bulan Maret tahun 2016 dibentuklah kelompok usaha tenun yang diberi nama Kelompok Nine Penenun (KNP). Nine artinya perempuan, penenun yang berarti orang yang menenun, jadi Nine penenun merupakan perempuan yang menenun. Kepengurusan Kelompok ini terdiri atas ketua, sekretaris dan bendahara.

Kelompok Nine Penenun (KNP) adalah salah satu usaha perajin tenun sekaligus menjual kain tenun yang ada di Desa Pringgasela Selatan Lombok Timur, usaha ini berdiri pada tahun 20016 bertempat di Desa Pringgasela Selatan Lombok Timur. Produk yang di tawarkan Kelompok Nine Penenun (KNP) seperti kebanyakan perajin tenun lainnya di Desa Pringgasela Selatan Lombok Timur yaitu kain songket. Dengan motif Keker, Serat Penginang, Cungklik, dan motif Subahnallah.

Pada awal berdirinya Kelompok Nine Penenun (KNP) di Desa Pringgasela Selatan Lombok Timur memiliki pelanggan relatif sedikit, hal ini bisa terjadi pada prusahaan yang baru berdiri. Siring berjalannya waktu dan perkembangan Lombok (NTB) yang meningkat dalam pariwisata, membuat jumlah pelanggan atau konsumen Kelompok Nine Penenun (KNP) di Desa Pringgasela Selatan Lombok Timur mengalami peningkatan dari waktu ke waktu.

Terbentuknya KNP sebagai wadah bagi penenun di Desa Pringgasela Selatan untuk mencurahkan segala keluh kesah yang dialami, pertemuan demi pertemuan dilakukan demi memperkuat pemahaman dan pengetahuan mereka. Proses pengorganisasian dijalankan untuk menambah anggota KNP. Prose pengorganisasian dilakukan dengan mendekatkan diri dan melakukan pertemanan dengan tetangga dan orang-orang di Dusun lainnya. Semakin hari, anggota KNP semakin bertambah. Pesanan produk tenun pun semakin lancer.

Hasil penjualan Kelompok Nine Penenun (KNP) dari tahun ke tahun ini masih belum memenuhi target penjualan secara optimal. oleh karena itu Kelompok Nine Penenun (KNP) dmeninjau kembali atau meningkatkan penyebaran promosi dan meningkatkan kualitas produk kepada konsumen guna meningkatkan hasil penjualan yang optimal. 
Melihat kondisi tersebut pengurus berinisiatif membuat sebuah wadah dengan nama Bale Tenun sebagai tempat untuk mengumpulkan hasil produk tenun dari para anggota. Bale Tenun berlokasi di salah satu rumah pengurus sebagai tempat sementara.

Keberadaan Bale Tenun semakin mempermudah kelompok untuk mengontrol hasil produk mereka. Bale tenun ini tidak seperti arshop yang hanya memajang hasil produksi tapi dibuat sebagai wadah untuk berkumpul, silaturahmi dan berbagi ilmu dan pengetahuan di bidang pertenunan agar dapat meningkatkan keakraban dan kesejahteraan bersama.

\section{METODE PENELITIAN}

\section{Jenis Penelitian}

Dalam penelitian ini Jenis Penelitian yang digunakan adalah penelitian Asosiatif, yaitu merupakan penelitian yang bertujuan untuk mengetahui pengaruh dan juga hubungan antara dua variabel atau lebih (Sugiyono, 2010). Penelitian ini mempunyai tingkatan tertinggi dibandingkan dengan diskriptif dan komparatif karena dengan penelitian ini dapat dibangun suatu teori yang dapat berfungsi untuk menguraikan, menjelaskan, meramalkan dan mengontrol suatu gejala yang ada. Dalam penelitian ini nantinya akan menjelaskan hubungan kausal antar variable promosi X1 dan kualitas produk X2 berpengaruh terhadap keputusan pembelian konsumen (Y) pada Kelompok Nine Penenun (KNP) di Desa Pringgasela Selatan Lombok Timur.

\section{Teknik Pengumpulan Data}

\section{a. Angket (Kuisioner)}

Angket atau kuisioner merupakan teknik pengumpulan data yang dilakukan dengan cara memberikan sejumlah pertanyaan tertulis yang digunakan untuk memperoleh informasi dari responden dalam arti laporan tentang pribadinya, atau hal-hal yang ia ketahui (Arikunto, 2014). Yang dapat dijaring dengan menggunakan kuesioner adalah meliputi hal-hal mengenai diri responden, dengan asumsi bahwa respondenlah yang paling mengetahui tentang dirinya sendiri dan pengalamannya sendiri karena dia sendiri sebagai pelaku, bahwa apa yang disampaikan oleh para responden kepada peneliti adalah benar, bahwa penafsiran subjek terhadap daftar pertanyaan-pertanyaan yang diajukan adalah sama dengan yang dimaksudkan oleh peneliti sendiri di lapangan.

\section{b. Skala interval}

Menurut Sugiyono, (2000:29), yaitu dengan membagi skor jawaban kedalam beberapa klas interval, dari klas variable X1 promosi sangat setuju sampai sangat tidak setuju. kelas Variable X2 kualitas produk dari sangat setuju sampai sangat tidak setuju. Dan klas Variable Y keputusan konsumen dalam pembelian dari sangat setuju sampai sangat tidak setuju.

\section{c. Observasi}

Observasi merupakan teknik pengumpulan data mempunyai ciri yang spesifik bila dibandingkan dengan teknik yang lain, yaitu wawancara dan kuesioner. Kalau wawancara dan kuesioner selalu berkomunikasi dengan orang lain, maka observasi tidak terbatas pada orang, tetapi juga obyek-obyek alam yang lain (Sugiyono: 2012: 145).

\section{Populasi, Sampel dan Teknik Pengambilan Sempel}

\section{a. Populasi}

Populasi merupakan wilayah generalisasi yang terdiri atas: obyek/subyek yang mempunyai kualitas dan karakteristik tertentu yang ditetapkan oleh peneliti untuk dipelajari dan kemudian ditarik kesimpulannya (Sugiyono, 2015). 
Populasi dalam penelitian ini adalah konsumen kerajinan Kelompok Nine Penenun (KNP) di Desa Pringgasela Selatan yang tidak di ketahui jumlahnya.

b. Sampel

Sampel adalah bagian dari jumlah dan karakteristik yang dimiliki oleh populasi. Sampel yang diambil dari populasi harus betul-betul representatif (mewakili) (Sugiyono, 2015).

Menurut Roscoe dalam Bila dalam penelitian akan melakukan analisis dengan multivariate (korelasi atau regresi ganda misalnya), maka jumlah anggota sampel minimal 10 kali dari jumlah variabel yang diteliti.

Jumlah variabel dalam penelitian ini adalah 3, dan menggunakan 20 kali dari jumlah variable. Maka jumlah anggota sampel $=3$ x $20=60$. Jadi jumlah sampel yang diambil adalah 60 orang konsumen yang dianggap mewakili populasi dari kerajinan Kelompok Nine Penenun (KNP) di Desa Pringgasela Selatan.

c. Teknik Pengambilan Sampel

Teknik yang digunakan dalam penelitian ini adalah nonprobability sampling. Menurut Sugiyono (2014: 84) Nonprobability sampling adalah teknik pengambilan sampel yang tidak memberi peluang/kesempatan sama bagi setiap unsur atau anggota populasi untuk dipilih menjadi sampel. Jenis nonprobability sampling yang digunakan adalah sampling purposive. Menurut Sugiyono (2014: 85) Sampling purposive adalah teknik penentuan sampel dengan pertimbangan tertentu. Adapun kriteria dari sampel penelitian ini adalah:

1. Konsumen yang membeli kain tenun di Kelompok Nine Penenun (KNP) di Desa Pringgasela Selatan.

2. Konsumen dalam negeri atau konsumen Lokal.

\section{Jenis dan sumber Data}

a. Jenis data yang digunakan dalam penelitian ini adalah:

1. Data kualitatif, kualtitaif yaitu penelitian yang dimaksud untuk memahami fenomena tentang apa yang dialami oleh subjek penelitian secara holistic dan dengan cara deskripsi dalam bentuk kata-kata dan bahasa, pada suatu konteks khusus yang alamiah dan dengan memanfaatkan berbagai metode alamiah (Moleong, 2011).

2. Data kuantitatif, kuantitatif yaitu data yang berbentuk angka, atau data kuantitatif yang diangkakan scoring) data tersebut dapat berupa angka atau skor dan biasanya diperoleh dengan menggunakan alat pengumpul data yang jawabannya berupa rentang skor atau pertanyaan yang diberi bobot (Sugiyono, 2015).

b. Sumber data dari penelitian ini adalah:

Menurut Sigiyono (2017 : 137) jika dilihat dari sumbernya data terbagi menjadi dua yaitu data primer dan data sekunder.

1. Data primer adalah data yang diperoleh secara langsung dari hasil wawancara, observasi dan kuisioner yang disebarkan kepada sejumlah sampel responden yang sesuai dengan target sasaran dan dianggap mewakili seluruh populasi yang dalam penelitian ini yaitu Konsumen Kelompok Nine Penenun (KNP) Desa Pringgasela Selatan Lombok Timur.

2. Data sekunder, yaitu merupakan data yang diperoleh dari pihak lain secara tidak langsung, memiliki hubungan dengan penelitian yang dilakukan berupa sejarah perusahaan, ruang lingkup perusahaan, struktur organisasi, buku, literature, artikel, serta situs di internet. 


\section{Identifikasi dan Definisi Operasional Variabel}

a. Identifikasi Variabel

Variabel-variabel yang dgunakan dalam penelitian ini adalah variabel independen (bebas) dan dependen (terikat).

1. Variabel bebas adalah merupakan variabel yang mempengaruhi atau yang menjadi sebab perubahannya atau timbulnya variabel dependen (terikat) (Sugiyono: 2012: 39).

(X1)= Promosi

$(\mathrm{X} 2)=$ Kualitas produk

2. Variabel terikat merupakan variabel yang dipengaruhi atau yang menjadi akibat, karena adanya variabel bebas (Sugiyono: 2012: 39).

$(\mathrm{Y})=$ Keputusan Pembelian

b. Definisi Operasional Variabel

1. Promosi (X1)

Menurut (Lupiyoadi \& Hamdani, 2001) mendefinisikan pengertian promosi yaitu: Promosi adalah kegiatan yang dilakukan perusahaan untuk mengkomunikasikan manfaat produk dan sebagai alat untuk mempengaruhi konsumen dalam kegiatan pembelian atau penggunaan jasa sesuai dengan kebutuhan.

Promosi memiliki indikator sebagai berikut:
a. Pesan promosi
b. Naskah promosi
c. Desain promosi
d. Model promosi

2. Kualitas produk (X2)

Kualitas produk merupakan kemampuan sutau produk dalam memenuhi keinginan konsumen (Kotler \& Armstrong, 2015). Dalam hal ini melihat kualitas kerajinan kain tenun pada Kelompok Nine Penenun (KNP) di Desa Pringgasela Selatan sehingga dapat memenuhi keinginan dan kebutuhan konsumen.

Kualitas produk memiliki indikator sebagai berikut:
a. Performance (kinerja)
b. Durability (daya tahan)
c. Conformance to Specifications (kesesuaian dengan spesifikasi),
d. Features (fitur)
e. Reliabilty (reliabilitas)
f. Aesthetics (estetika)
g. Perceived Quality (kesan kualitas)

3. Keputusan pembelian (Y)

Keputusan pembelian adalah tindakan dari konsumen untuk mau membeli atau tidak terhadap suatu produk atau jasa. Dari berbagai faktor yang mempengaruhi dalam melakukan pembelian suatu produk atau jasa biasanya konsumen selalu mempertimbangkan kualitas, harga dan produk yang sudah dikenal masyarakat.

Keputusan pembelian memiliki indikator sebagai berikut:
a. Pengenalan masalah
b. Pencarian informasi
c. Evaluasi alternatif
d. Keputusan membeli
e. Perilaku pasca pembelian 


\section{Teknik Analisis Data}

\section{A. Uji Validitas}

Menurut Ghiselli et al dalam (Jogiyanto, 2014) Validitas adalah menunjukkan seberapa jauh suatu tes atau satu set dari operasi-operasi mengukur apa yang seharusnya diukur.

Menurut Azwar dalam (Jogiyanto, 2014) Validitas adalah sejauh mana ketepatan dan kecermatan suatu alat ukur dalam melakukan fungsi ukurnya.

B . Uji Reliabilitas

Menurut Sekaran di dalam (Jogiyanto, 2014) Reliabilitas adalah suatu pengukur menunjukkan stabilitas dan konsistensi dari suatu instrumen yang mengukur suatu konsep dan berguna mengakses "kebaikan" dari suatu pengukur.

\section{C . Uji Asumsi Klasik}

Menurut Duwi (2012: 143) Model regresi linier dapat disebut sebagai model yang baik jika model tersebut memenuhi beberapa asumsi yang kemudian disebut dengan asumsi klasik.

Asumsi yang harus terpenuhi dalam model regresi linier yaitu residual terdistribusi normal, tidak adanya multikolinearitas, tidak adanya hteroskedastisitas, dan tidak adanya autokerelasi pada model regresi

\section{Uji Normalitas}

Uji normalitas pada model regresi digunakan untuk menguji apakah nilai residual yang dihasilkan dari regresi terdistribusi secara normal atau tidak.

\section{Uji Multikolinearitas}

Menurut Ghozali (2012 : 105 Uji multikolinearitas bertujuan untuk menguji apakah suatu model regresi terdapat korelasi antara variable bebas (independen).

3. Uji Heteroskedastisitas

Heteroskedastisitas adalah keadaan di mana dalam model regresi terjadi ketidaksamaan varian dari residual pada satu pengamatan ke pengamatan lain. Model regresi yang baik adalah tidak terjadi heteroskedastisitas.

\section{Analisis Regresi Linier Berganda}

Analisis regresi linier berganda digunakan oleh peneliti, bila peneliti bermaksud meramalkan bagaimana keadaan (naik turunnya) variabel dependen (kriterium), bila dua atau lebih variabel independen sebagai faktor prediktor dimanipulasi (dinaik turunkan nilainya). Jadi analisis regresi ganda akan dilakukan apabila jumlah variabel independennya minimal dua (Sugiyono: 2015: 275).

Metode analisis yang digunakan untuk membahas dalam penelitian ini adalah metode regresi linier berganda, rumus model regresi linier berganda adalah sebagai berikut:

$\mathrm{Y}=\mathrm{a}+\mathrm{b} 1 \mathrm{X} 1+\mathrm{b} 2 \mathrm{X} 2+\mathrm{e}$

Dimana:

$\mathrm{Y}=$ Keputusan pembelian

a $=$ Konstanta

b1 = Standar koefisien regresi dari promosi

b2 = Standar koefisien regresi dari kualitas produk

$\mathrm{X} 1=$ Promosi

$\mathrm{X} 2$ = kualitas produk

$\mathrm{e} \quad=$ Error

Uji F (Simultan) 
Uji statistik F pada dasarnya menunjukkan apakah semua variabel independen atau bebas yang dimasukkan dalam model mempunyai pengaruh secara bersama-sama terhadap variabel dependen atau terikat (Ghozali, 2005). Hipotesis nol ( ) yang hendak diuji adalah apakah semua parameter dalam model sama dengan nol, artinya apakah semua variabel independen bukan merupakan penjelas yang signifikan terhadap variabel dependen.

Uji t (Parsial)

Uji statistik t pada dasarnya menunjukkan seberapa jauh pengaruh satu variabel independen secara individual dalam menerangkan variasi variabel dependen (Ghozali, 2005). Hipotesis yang hendak diuji adalah apakah suatu parameter sama dengan nol, artinya apakah suatu variabel independen bukan merupakan penjelas yang signifikan terhadap variabel dependen.

Koefisien Determinasi

Koefisien determinasi ( ) pada intinya mengukur seberapa jauh kemampuan model dalam menerangkan variasi variabel dependen. Nilai koefisien determinasi adalah antara nol dan satu. Nilai yang kecil berarti kemampuan variabel-variabel independen dalam menjelaskan variasi variabel dependen amat terbatas. Nilai yang mendekati satu berarti variabel-variabel independen memberikan hampir semua informasi yang dibutuhkan untuk memprediksi variasi variabel dependen.

\section{HASIL DAN PEMBAHASAN}

\section{Deskripsi Data}

Penelitian ini secara umum menggunakan data primer yang diperoleh langsung dari responden. Pengambilan data pada responden dilakukan melalui pengajuan daftar pertanyaan yang di isi dan dijawab oleh responden, sedangkan data sekunder diperoleh dari buku-buku referensi yang berkaitan dengan penelitian dan merupakan data pendukung untuk lebih mengarahkan pada tujuan penelitian.

\section{a. Deskripsi Objek Penelitian}

Kelompok Nine Penenun (KNP) di Desa Pringgasela Selatan adalah salah satu usaha perajin tenun sekaligus menjual kain tenun yang ada di Desa Pringgasela Selatan Lombok Timur, usaha ini berdiri pada tahun 2001 bertempat Pringgasela Lombok Timur. Lokasi Pringgasela Selatan ini sekitar $50 \mathrm{Km}$ dari kota Mataram atau sekitar 1Jam perjalanan, dan sekitar $20 \mathrm{Km}$ dari kota Selong atau 20 menit perjalanan dengan menggunakan kendaraan pribadi atau taksi. Sebagian besar perempuan yang ada di Desa Pringgasela Selaatan ini bekerja sebagai penenun.

b. Deskripsi Responden

Responden yang menjadi sampel pada penelitian ini sebanyak 60 responden adalah konsumen yang membeli kain tenun di Kelompok Nine Penenun (KNP) di Desa Pringgasela Selatan dan berusia di atas 18 tahun. Adapun gambaran jumlah responden yang membeli kain tenun di Kelompok Nine Penenun (KNP) di Desa Pringgasela Selatan sesuai dengan kriteria yang telah ditentukan adalah sebagai berikut:

2. Deskripsi Responden Berdasarkan Usia

Responden yang membeli kain tenun di Kelompok Nine Penenun (KNP) di Desa Pringgasela Selatan dapat diklasifikasikan berdasarkan usia. Adapun kriteria responden berdasarkan usia responden dapat diuraikan pada tabel berikut: 
Tabel 1. Deskripsi Responden Berdasarkan Usia

\begin{tabular}{|l|c|c|c|}
\hline No. & $\begin{array}{c}\text { ia Responden } \\
\text { (Tahun) }\end{array}$ & $\begin{array}{c}\text { Jumlah } \\
\text { (Orang) }\end{array}$ & $\begin{array}{c}\text { Persentase } \\
(\%)\end{array}$ \\
\hline 1 & $18-20$ & 20 & 33,33 \\
\hline 2 & $21-25$ & 14 & 23,33 \\
\hline 3 & $26-30$ & 8 & 13,34 \\
\hline 4 & $\geq 30$ & 18 & 30 \\
\hline 5 & Total & 60 & 100 \\
\hline & & & \\
\hline
\end{tabular}

Sumber : Data Primer dan Sekunder yang telah diolah

Berdasarkan tabel di atas dapat dilihat bahwa responden yang paling banyak membeli kain tenun di Kelompok Nine Penenun (KNP) di Desa Pringgasela Selatan adalah responden yang berusia 18-20 tahun keatas yaitu sebanyak 20 orang dengan persentase $33,33 \%$.

Responden yang berusia 21 tahun sampai dengan 25 tahun sebanyak 14 orang dengan persentase $23,33 \%$. Responden yang berusia 26 tahun sampai dengan 30 tahun sebanyak 8 orang dengan persentase $13,34 \%$. Selanjutnya responden yang berusia 30 tahun ke atas sebanyak 18 orang dengan persentase $30 \%$.

3. Deskripsi Jawaban Responden

Setiap kuesioner yang dibagikan kepada responden yang berjumlah 60 orang. Jawaban yang diberikan oleh masing-masing responden berbeda-beda terhadap pernyataan yang terdapat pada kuesioner. Berdasarkah hasil penelitian yang telah dilakukan pada Kelompok Nine Penenun (KNP) di Desa Pringgasela Selatan, adapun jawaban responden terhadap kuesioner yang dibagikan dapat dilihat pada tabel sebagai berikut:

\section{Tabel 2. Deskripsi Jawaban Responden Promosi Terhadap Keputusan Pembelian Pada Kain Tenun di Kelompok Nine Penenun (KNP) di Desa Pringgasela Selatan Lombok}

Timur

\begin{tabular}{|c|l|l|l|l|l|l|l|l|}
\hline \multirow{2}{*}{ No. } & Indikator/pertanyaan & \multicolumn{5}{|c|}{ Jawaban Responden } & \multirow{2}{*}{ Jumlah } & atarata \\
\cline { 3 - 8 } & & SS(5) & S(4) & N(3) & TS(2) & STS(1) & & \\
\hline 1 & Pesan promosi & 15 & 38 & 7 & - & - & 248 & 4,1 \\
\hline 2 & Naskah promosi & 9 & 42 & 9 & - & - & 240 & 4 \\
\hline 3 & Desain promosi & 11 & 29 & 20 & - & - & 231 & 3,8 \\
\hline 4 & Model promosi & 19 & 33 & 8 & - & - & 251 & 4,1 \\
\hline
\end{tabular}

Sumber: Data Primer dan Sekunder yang telah diolah

Berdasaran table di atas dapat di lihat bahwa indikator atau pertanyaan model promosi memiliki jumlah tertinggi sebanyak 19 responden menjawab sangat setuju, 33 menjawab setuju, 8 menjawab netral dengan jumlah keseluruhan 251 dan indikator atau pertanyaan desain promossi yang memiliki jumlah paling rendah sebanyak 11 respoden menjawab sangat setuju, 29 menjawab setuju, 20 menjawab netral dengan jumlah keseluruhan 231 . 
Tabel 3. Deskripsi Jawaban Responden Kualitas Produk Terhadap Keputusan Pembelian Pada Kain Tenun di Kelompok Nine Penenun (KNP) di Desa Pringgasela Selatan Lombok Timur

\begin{tabular}{|l|l|c|c|c|c|c|c|c|}
\hline \multirow{2}{*}{ No } & Indikator/pertanyaan & \multicolumn{5}{|c|}{ Jawaban Responden } & jumlah & $\begin{array}{c}\text { Rata- } \\
\text { rata }\end{array}$ \\
\cline { 3 - 7 } & & SS(5) & S(4) & N(3) & TS(2) & STS(1) & & 4,1 \\
\hline $\mathbf{1}$ & Kinerja & 19 & 33 & 8 & - & - & 251 & 4 \\
\hline $\mathbf{2}$ & Daya tahan & 19 & 27 & 14 & - & - & 245 & 4 \\
\hline $\mathbf{3}$ & $\begin{array}{l}\text { Kesesuaian dengan } \\
\text { spesifikasi }\end{array}$ & 14 & 38 & 8 & - & - & 246 & 4,1 \\
\hline $\mathbf{4}$ & Fitur & 15 & 38 & 6 & 1 & - & 247 & 4,1 \\
\hline $\mathbf{5}$ & Reliabilitas & 16 & 36 & 7 & 1 & - & 247 & 4,1 \\
\hline $\mathbf{6}$ & Estetika & 17 & 30 & 12 & 1 & - & 243 & 4 \\
\hline $\mathbf{7}$ & Kesan kualitas & 19 & 34 & 7 & - & - & 252 & 4,2 \\
\hline
\end{tabular}

Sumber : Data Primer dan Sekunder yang telah diolah

Berdasaran table di atas dapat di lihat bahwa indikator atau pertanyaan kesan kualitas memiliki jumlah tertinggi sebanyak 19 responden menjawab sangat setuju, 34 menjawab setuju, 7 menjawab netral dengan jumlah keseluruhan 252 dan indikator atau pertanyaan Estetika yang memiliki jumlah paling rendah sebanyak 17 respoden menjawab sangat setuju, 30 menjawab setuju, 12 menjawab netral, 1 menjawab tidak setuju dengan jumlah keseluruhan 243.

Tabel 4. Deskripsi Jawaban Responden Keputusan Pembelian Pada Kain Tenun di Kelompok Nine Penenun (KNP) di Desa Pringgasela Selatan Lombok Timur

\begin{tabular}{|l|l|c|c|c|c|c|c|c|}
\hline \multirow{2}{*}{ No } & Indikator/pertanyaan & \multicolumn{5}{|c|}{ Jawaban Responden } & Jumlah & $\begin{array}{c}\text { Rata- } \\
\text { rata }\end{array}$ \\
\cline { 3 - 7 } & & SS(5) & S(4) & N(3) & TS(2) & STS(1) & & \\
\hline 1 & Pengenalan masalah & 20 & 26 & 14 & - & - & 246 & 4,1 \\
\hline 2 & Pencarian informasi & 13 & 38 & 9 & - & - & 244 & 4 \\
\hline 3 & Evaluasi alternatif & 17 & 36 & 6 & 1 & - & 247 & 4,1 \\
\hline 4 & Keputusan membeli & 20 & 32 & 8 & - & - & 252 & 4,2 \\
\hline 5 & Periaku pasca membeli & 21 & 33 & 6 & - & - & 255 & 4,2 \\
\hline
\end{tabular}

Sumber : Data Primer dan Sekunder yang telah diolah

Berdasaran table di atas dapat di lihat bahwa indikator atau pertanyaan Perilaku pasca membeli memiliki jumlah tertinggi sebanyak 21 responden menjawab sangat setuju, 33 menjawab setuju, 6 menjawab netral dengan jumlah keseluruhan 255. dan indikator atau pertanyaan pencarian informasi yang memiliki jumlah paling rendah sebanyak 13 respoden menjawab sangat setuju, 38 menjawab setuju, 9 menjawab netral dengan jumlah keseluruhan 244.

4. Analisis Data

a. Uji Validitas

Uji validitas menunjukkan seberapa nyata suatu pengujian mengukur apa yang seharusnya diukur. Dalam penelitian ini untuk menentukan tingkat valid suatu item 
Masbullah dan Salmi Yuniar Bahri

instrumen adalah dengan mencapai koefisien korelasi minimal 0,30 daya pembedanya dianggap memuaskan dan item yang memiliki nilai koefisien korelasi dibawah 0,30 dianggap tidak valid.

Adapun hasil pengujian validitas menggunakan program SPSS sebagai berikut:

Tabel 5. Hasil Uji Validitas

\begin{tabular}{|c|c|c|c|c|}
\hline No & $\begin{array}{c}\text { Butir } \\
\text { Kuesioner }\end{array}$ & $\begin{array}{c}\text { Nilai } \\
\text { Korelasi }\end{array}$ & $\begin{array}{c}\text { Standar } \\
\text { Korelasi }\end{array}$ & Keterangan \\
\hline 1 & $\mathrm{X} 1.1$ & 0,726 & 0,30 & VALID \\
\hline 2 & $\mathrm{X} 1.2$ & 0,770 & 0,30 & VALID \\
\hline 3 & $\mathrm{X} 1.3$ & 0,760 & 0,30 & VALID \\
\hline 4 & $\mathrm{X} 1.4$ & 0,781 & 0,30 & VALID \\
\hline 5 & $\mathrm{X} 2.1$ & 0,660 & 0,30 & VALID \\
\hline 6 & $\mathrm{X} 2.2$ & 0,765 & 0,30 & VALID \\
\hline 7 & $\mathrm{X} 2.3$ & 0,781 & 0,30 & VALID \\
\hline 8 & $\mathrm{X} 2.4$ & 0,643 & 0,30 & VALID \\
\hline 9 & $\mathrm{X} 2.5$ & 0,730 & 0,30 & VALID \\
\hline 10 & $\mathrm{X} 2.6$ & 0,766 & 0,30 & VALID \\
\hline 11 & $\mathrm{X} 2.7$ & 0,713 & 0,30 & VALID \\
\hline 12 & $\mathrm{Y} .1$ & 0,774 & 0,30 & VALID \\
\hline 13 & $\mathrm{Y} .2$ & 0,752 & 0,30 & VALID \\
\hline 14 & $\mathrm{Y} .3$ & 0,683 & 0,30 & VALID \\
\hline 15 & $\mathrm{Y} .4$ & 0,784 & 0,30 & VALID \\
\hline 16 & $\mathrm{Y} .5$ & 0,766 & 0,30 & VALID \\
\hline
\end{tabular}

Sumber: Hasil Pengolahan database SPSS

Berdasarkan tabel diatas dapat dilihat bahwa semua item yang terdapat pada kuesioner penelitian ini memiliki koefisien korelasi lebih dari 0,30. Hal ini menunjukkan bahwa semua item kuesioner valid.

b. Uji Reliabilitas

Uji reliabilitas menunjukkan akurasi dan ketepatan dari pengukurnya. Suatu pengukur dikatakan reliabel (dapat diandalkan) jika dapat dipercaya, supaya dapat dipercaya maka hasil dari pengukuran harus akurat dan konsisten. Pada penelitian ini untuk menunjukkan suatu instrument dikatakan reliabel adalah menggunakan batas alpha 0,6. Reliabilitas kurang dari 0,6 adalah kurang baik, sedangkan 0,7 dapat diterima dan diatas 0,8 adalah baik.

Adapun hasil pengujian reliabilitas menggunakan program SPSS adalah sebagai berikut:

Tabel 6. Hasil Uji Reliabilitas

\begin{tabular}{|c|c|c|c|c|}
\hline No & Variabel & $\begin{array}{c}\text { Nilai } \\
\text { Alpha }\end{array}$ & $\begin{array}{c}\text { Standar } \\
\text { Alpha }\end{array}$ & Keterangan \\
\hline 1 & Promosi & 0,801 & 0,6 & Reliabel \\
\hline 2 & Kualitas Produk & 0,779 & 0,6 & Reliabel \\
\hline 3 & Keputusan Pembelian & 0,793 & 0,6 & Reliabel \\
\hline
\end{tabular}

Sumber: Hasil Pengolahan database SPSS

Berdasarkan tabel diatas dapat dilihat bahwa semua item pada instrumen ini memiliki nilai 
Masbullah dan Salmi Yuniar Bahri

alpha diatas 0,6. Hal ini menunjukkan bahwa semua item pada instrument penelitian ini sudah reliabel.

\section{Asumsi Klasik}

Sebelum melakukan sebuah analisis dalam model regresi ada prasyarat yang harus terpenuhi terhadap data yang telah dikumpulkan yaitu dengan melakukan uji asumsi klasik.

a.Uji Normalitas

Uji normalitas digunakan untuk menguji apakah nilai residual yang dihasilkan dari regresi terdistribusi secara normal atau tidak. Metode yang digunakan pada penelitian adalah metode grafik yaitu melihat penyebaran data pada sumber diagonal pada grafik normal P-P Plot of regression standardized residual. Adapun hasil pengujian normalitas menggunakan SPSS adalah sebagai berikut:

\section{Tabel 7. Hasil Uji Normalitas Dengan Menggunakan Grafik Normal P-P}

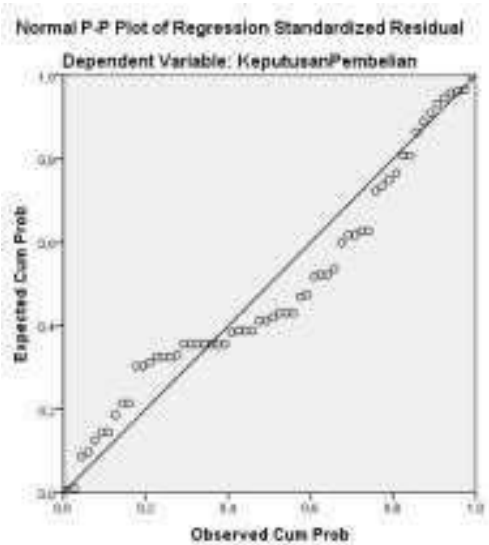

Berdasarkan gambar diatas dapat dilihat bahwa titik-titik telah menyebar sesuai sekitar garis dan mengikuti garis diagonal. Hal ini menujukkan bahwa data pada penelitian ini sudah terdistribusi secara normal.

b. Uji Multikolinearitas

Uji multikolinearitas digunakan untuk mengetahui ada tidaknya masalah multikolinearitas, yaitu adanya hubungan linier antar variabel independen dalam model regresi. Pada penelitian ini untuk mendeteksi ada tidaknya masalah multikolinearitas adalah dengan melihat nilai tolerance harus lebih dari 0,1 dan nilai VIF kurang dari 10 maka hal ini menujukkan bahwa tidak terjadi masalah multikoleniaritas.

Adapun hasil pengujian multikolinearitas menggunakan SPSS adalah sebagai berikut:

\section{Tabel 8. Hasil Uji Multikolinearitas}

\begin{tabular}{|c|c|c|c|c|c|c|c|c|}
\hline \multicolumn{9}{|c|}{ Coefficients $^{\mathrm{a}}$} \\
\hline \multirow{2}{*}{\multicolumn{2}{|c|}{ Model }} & \multicolumn{2}{|c|}{ Unstandardized Coefficients } & \multirow{2}{*}{$\begin{array}{c}\begin{array}{c}\text { Standardized } \\
\text { Coefficients }\end{array} \\
\text { Beta }\end{array}$} & \multirow[t]{2}{*}{$\mathrm{t}$} & \multirow{2}{*}{ Sig. } & \multicolumn{2}{|c|}{ Collinearity Statistics } \\
\hline & & B & Std. Error & & & & Tolerance & VIF \\
\hline \multirow{3}{*}{1} & (Constant) & ,005 & 210 & &, 025 & ,980 & & \\
\hline & $\mathrm{X} 1$ & ,391 &, 076 & ,376 & 5,111 &, 000 & ,407 & 2,456 \\
\hline & $\mathrm{X} 2$ & ,624 &, 075 & ,615 & 8,358 & , 000 & ,407 & 2,456 \\
\hline
\end{tabular}

a. Dependent Variable: Y keputuan pembelian

Berdasarkan tabel diatas dapat dilihat bahwa nilai tolerance setiap variabel diatas 0,1 dan memiliki nilai VIF diatas 10. Hal ini menunjukkan bahwa data pada penelitian ini tidak terjadi masalah multikoleniaritas. 
c. Uji Heteroskedastisitas

Heteroskedastisitas adalah keadaan dimana dalam model regresi terjadi ketidaksamaan varian residual pada satu pengamatan ke pengamatan lain. Pada penelitian ini metode yang digunakan pada penelitian ini adalah uji glejser. Jika nilai signifikan antara variabel independen dengan absolute residualnya lebih dari 0,05 maka tidak terjadi heteroskedastisitas.

Adapun hasil pengujian heteroskedastisitas menggunakan SPSS adalah sebagai berikut:

\section{Tabel 9. Hasil Uji Heteroskedastisitas}

\begin{tabular}{|c|c|c|c|c|c|c|c|c|}
\hline \multicolumn{9}{|c|}{ Coefficients $^{\mathbf{a}}$} \\
\hline \multirow{2}{*}{\multicolumn{2}{|c|}{ Model }} & \multicolumn{2}{|c|}{$\begin{array}{l}\text { Unstandardized } \\
\text { Coefficients }\end{array}$} & \multirow{2}{*}{$\begin{array}{c}\begin{array}{c}\text { Standardized } \\
\text { Coefficients }\end{array} \\
\text { Beta }\end{array}$} & \multirow[t]{2}{*}{$\mathrm{t}$} & \multirow[t]{2}{*}{ Sig. } & \multicolumn{2}{|c|}{ Collinearity Statistics } \\
\hline & & B & Std. Error & & & & Tolerance & VIF \\
\hline \multirow{3}{*}{1} & (Constant) & ,208 &, 142 & & 1,465 & , 148 & & \\
\hline & $\mathrm{X} 1$ & ,013 &, 052 &, 053 & ,258 & ,797 & ,407 & 2,456 \\
\hline & $\mathrm{X} 2$ &,- 032 &, 050 &,- 133 &,- 642 &, 523 & ,407 & 2,456 \\
\hline
\end{tabular}

Berdasarkan tabel diatas dapat dilihat bahwa nilai signifikan setiap variabel independen terhadap absolute residualnya adalah diatas 0,05 . Hal ini menujukkan bahwa data pada penelitian ini tidak terjadi heteroskedastisitas.

6. Analisis Regresi Linier Berganda

Analisis regresi linier berganda digunakan untuk mengetahui pengaruh dari variabel independen yang jumlahnya lebih dari satu terhadap variabel dependen.

Adapun hasil analisis regresi linier berganda menggunakan SPSS adalah sebagai berikut:

Tabel 10. Hasil Analisis Regresi Linier Berganda

Coefficients $^{\mathbf{a}}$

\begin{tabular}{|c|c|c|c|c|c|c|}
\hline \multirow{2}{*}{\multicolumn{2}{|c|}{ Model }} & \multicolumn{2}{|c|}{ Unstandardized Coefficients } & \multirow{2}{*}{$\begin{array}{c}\begin{array}{c}\text { Standardized } \\
\text { Coefficients }\end{array} \\
\text { Beta }\end{array}$} & \multirow[t]{2}{*}{$\mathrm{T}$} & \multirow[t]{2}{*}{ Sig. } \\
\hline & & B & Std. Error & & & \\
\hline \multirow{3}{*}{1} & (Constant) &, 005 & ,210 & &, 025 & ,980 \\
\hline & $\mathrm{X} 1$ & ,391 & 076 & ,376 & 5,111 & ,000 \\
\hline & $\mathrm{X} 2$ & ,624 & 075 & ,615 & 8,358 & ,000 \\
\hline
\end{tabular}

Persamaan Regresi Linier Berganda:

$\mathrm{Y}=0,005+0,391 \mathrm{X} 1+0,624 \mathrm{X} 2+\mathrm{e}$

Berdasarkan persamaan regresi linier berganda diatas dapat dilihat bahwa nilai konstanta (a) sama dengan 0,005 berarti bahwa apabila nilai variabel bebas sama dengan nol, maka besarnya variabel terikat adalah 0,005. Dengan kata lain besarnya keputusan pembelian tanpa adanya pengaruh dari promosi dan kualitas produk adalah 0,005 .

a. Uji t (Parsial)

Uji $\mathrm{t}$ yaitu untuk mengetahui pengaruh signifikan permasing-masing variabel independen terhadap variabel dependen. Adapun kriteria dalam melakukan uji t adalah dengan cara membandingkan nilai statistik t dengan titik kritis menurut tabel. Apabila nilai t hasil perhitungan lebih tinggi dibandingkan nilai t tabel, kita menerima hipotesis alternatif yang menyatakan bahwa suatu variabel independen secara individual mempengaruhi variabel dependen.

Untuk menentukan nilai $\mathrm{t}$ tabel adalah dengan menentukan tingkat kepercayaan $(\alpha)$ dibagi dua karena pada penelitian ini uji t dilakukan pengujian dua arah dan menentukan nilai df (degree of freedom) atau derajat bebas. Cara menentukan df adalah jumlah 
Masbullah dan Salmi Yuniar Bahri

responden (n) dikurangi dengan jumlah variabel bebas dan terikat (k). Jika ditulis dalam bentuk rumus adalah sebagai berikut $\mathrm{t}$ tabel $=\alpha / 2 ; \mathrm{n}-\mathrm{k}$.

Adapun hasil uji t (parsial) menggunakan program SPSS adalah sebagai berikut:

Tabel 11. Hasil Uji t (Parsial)

\begin{tabular}{|c|c|c|c|c|}
\hline No & Variabel & $\begin{array}{c}\text { Nilai } \\
\text { t Hitung }\end{array}$ & $\begin{array}{c}\text { Nilai } \\
\text { t Tabel }\end{array}$ & Keterangan \\
\hline 1 & Promosi & 5,111 & 2,00247 & Signifikan \\
\hline 2 & Kualitas Produk & 8,358 & 2,00247 & Signifikan \\
\hline
\end{tabular}

Sumber: Hasil Pengolahan database SPSS

Berdasarkan tabel diatas dapat dilihat bahwa nilai t tabel adalah sebesar 2,00247. Nilai $t$ tabel tersebut didapat dengan menentukan tingkat kepercayaan yaitu 0,05:2=0,025 dan menentukan df yaitu $60-3=57$. Hal ini menyatakan bahwa nilai t tabel dapat dilihat pada kolom tingkat kepercayaan 0,025 dan df pada kolom 57 yaitu sebesar 2,00247.

b. Uji F (Simultan)

Uji statistik F pada dasarnya menunjukkan apakah semua variabel independen atau bebas yang dimasukkan dalam model mempunyai pengaruh signifikan secara bersama-sama terhadap variabel dependen atau terikat. Pada penelitian ini untuk menguji hipotesis digunakan uji statistik $\mathrm{F}$ dengan kriteria pengambilan keputusan adalah membandingkan nilai $\mathrm{F}$ hitung dengan $\mathrm{F}$ tabel. Jika $\mathrm{F}$ hitung lebih besar dari $\mathrm{F}$ tabel maka variabel independen secara bersama terdapat pengaruh yang signifikan terhadap keputusan pembelian.

Adapun hasil uji F (Simultan) dengan menggunakan aplikasi program SPSS adalah sebagai berikut:

\section{Tabel 12. Hasil Uji F (Simultan)}

ANOVA $^{\mathrm{a}}$

\begin{tabular}{|ll|r|r|r|r|r|}
\hline Model & & Sum of Squares & df & Mean Square & F & Sig. \\
\hline \multirow{2}{*}{1} & Regression & 12,759 & 2 & 6,379 & 198,660 &, $000^{\mathrm{b}}$ \\
& Residual & 1,830 & 57 &, 032 & & \\
& Total & 14,589 & 59 & & & \\
\hline
\end{tabular}

a. Dependent Variable: Y

b. Predictors: (Constant), X2, X1

Berdasarkan tabel diatas dapat dilihat bahwa nilai df pembilang (N1) adalah 2 dan df penyebut (N2) adalah 57. Nilai N1 juga dapat dihitung dengan rumus $3-1=2$ dan $\mathrm{N} 2$ dapat dihitung dengan rumus $60-3=57$. Hal ini menyatakan bahwa $\mathrm{F}$ tabel terdapat pada kolom 2 pada df pembilang dan kolom 57 pada df penyebut yaitu sebesar 3,16.

Melihat nilai $\mathrm{F}$ hitung dan $\mathrm{F}$ tabel pada penelitian ini. Maka dapat dilihat bahwa $\mathrm{F}$ hitung memiliki nilai lebih besar dari F tabel yaitu 198,660>3,16. Hal ini menyatakan bahwa variabel promosi dan kualitas produk berpengaruh signifikan secara simultan terhadap keputusan pembelian.

\section{c. Koefisien Determinasi}

Koefisien determinasi ( ) pada intinya mengukur seberapa jauh kemampuan model dalam menerangkan variasi variabel dependen. Pada penelitian ini jika R2 sama dengan 1 maka variasi variabel bebas dapat dijelaskan sebesar 100\%, sebaliknya jika R2 sama dengan 0 maka variabel bebas tidak dapat dijelaskan.

Adapun hasil pengujian koefisien determinasi menggunakan SPSS adalah sebagai berikut: 
Tabel 13. Hasil Koefisien Determinasi

Model Summary ${ }^{\mathrm{b}}$

\begin{tabular}{|c|c|c|c|c|}
\hline Model & $\mathrm{R}$ & $\mathrm{R}$ Square & $\begin{array}{c}\text { Adjusted R } \\
\text { Square }\end{array}$ & $\begin{array}{c}\text { Std. Error of the } \\
\text { Estimate }\end{array}$ \\
\hline 1 &, $935^{\mathrm{a}}$ &, 875 &, 870 &, 17920 \\
\hline
\end{tabular}

a. Predictors: (Constant), X2, X1

b. Dependent Variable: Y

Berdasarkan tabel diatas dapat dilihat bahwa hasil analisis menunjukkan nilai koefisien determinasi (R square) adalah sebesar 0,875. Hal ini berarti kemampuan variabel independen dalam menjelaskan variasi variabel dependen sudah tinggi. Selanjutnya sisa dari nilai $\mathrm{R}$ Square yaitu sebesar 0,125 merupakan pengaruh dari variabel lain yang tidak di masukkan ke dalam penelitian.

\section{Pembahasan}

1. Berdasarkan hasil analisis pengujian secara parsial dapat dilihat bahwa variabel promosi memiliki nilai t hitung lebih besar sebesar 5,111 dibandingkan dengan nilai $\mathrm{t}$ tabel sebesar 2,00247. Dapat dikatakan bahwa variabel promosi berpengaruh signifikan terhadap keputusan pembelian dan variabel promosi memiliki pengaruh positif terhadap keputusan pembelian.

2. Variabel promosi memiliki pengaruh positif, artinya apabila variabel promosi meningkat maka variabel keputusan pembelian akan meningkat. Sedangkan apabila variabel promosi menurun maka keputusan pembelian akan menurun. Hal ini menunjukkan bahwa perubahan variabel promosi searah dengan variabel keputusan pembelian.

3. Variabel kualitas produk memiliki nilai t hitung lebih besar sebesar 8,358 dibandingkan dengan nilai t tabel sebesar 2,00247. Dapat dikatakan bahwa variabel kualitas produk berpengaruh signifikan terhadap keputusan pembelian dan variabel kualitas produk memiliki pengaruh positif terhadap keputusan pembelian.

4. Variabel kualitas produk memiliki pengaruh positif, artinya apabila variabel kualitas produk meningkat maka variabel keputusan pembelian akan meningkat. Sedangkan apabila variabel kualitas produk menurun maka keputusan pembelian akan menurun. Hal ini menunjukkan bahwa perubahan variabel kualitas produk searah dengan variabel keputusan pembelian.

5. Berdasarkan hasil analisis pengujian secara simultan dapat dilihat bahwa nilai $\mathrm{F}$ hitung dan $\mathrm{F}$ tabel pada penelitian ini. Maka dapat dilihat bahwa F hitung memiliki nilai lebih besar dari F tabel yaitu 198,660>3,16. Hal ini menyatakan bahwa variabel promosi dan kualitas produk berpengaruh signifikan secara simultan terhadap keputusan pembelian.

6. Berdasarkan hasil analisis koefisien determinasi dapat dilihat bahwa hasil analisis menunjukkan nilai koefisien determinasi ( $\mathrm{R}$ square) adalah sebesar 0,875. Hal ini berarti kemampuan variabel independen dalam menjelaskan variasi variabel dependen masih terbatas. Selanjutnya sisa dari nilai $\mathrm{R}$ Square yaitu sebesar 0,125 merupakan pengaruh dari variabel lain yang tidak di masukkan ke dalam penelitian. 


\section{KESIMPULAN}

Bahwa pengaruh promosi dan kualitas produk terhadap keputusan pembelian konsumen pada kerajinan tenun di Kelompok Nine Penenun (KNP) berpengaruh signifikan Berdasarkan variabel promosi memiliki nilai $\mathrm{t}$ hitung lebih besar sebesar 5,111 dibandingkan dengan nilai $\mathrm{t}$ tabel sebesar 2,00247. Dapat dikatakan bahwa variabel promosi berpengaruh signifikan terhadap keputusan pembelian. Berdasarkan variabel kualitas produk memiliki nilai t hitung lebih besar sebesar 8,358 dibandingkan dengan nilai t tabel sebesar 2,00247. Dapat dikatakan bahwa variabel kualitas produk berpengaruh signifikan terhadap keputusan pembelian dan variabel kualitas produk memiliki pengaruh positif terhadap keputusan pembelian. Pengaruh promosi dan kualitas produk menjadi lebih efektif dalam kepercayaan konsumen kain tenun Kelompok Nine Penenun (KNP) melalui pengenalan produk. Dan berdasarkan Nilai F hitung memiliki nilai lebih besar dari $\mathrm{F}$ tabel yaitu 198,660>3,16. Hal ini menyatakan bahwa variabel promosi dan kualitas produk berpengaruh signifikan secara simultan terhadap keputusan pembelian. Sehingga dapat disimpulkan berdasarkan analisis dan hasil penelitian ini bahwa pengaruh promosi dan kualitas produk terhadap keputusan pembelian konsumen pada kerajinan berpengaruh signifikan, memiliki pengaruh positif secara simultan terhadap keputusan pembelian pada Kelompok Nine Penenun (KNP) di Desa Pringgasela Sealata Lombok Timur. 


\section{Bibliografi}

Arikunto, Suharsimi. 2014. Prosedur Penelitian Suatu Pendekatan Praktik. Jakarta : Rineka Cipta.

Amstrong, Kolter. 2015. Marketing an Introducing prentice Hall twelfth edition. England: Pearson Education, Inc.

Abshor, Muhammad Ulil., Hasiolan, Leonardo B., dan Malik, Djamaludin. Pengaruh Harga, Promosi dan Kualitas Produk Terhadap Keputusan Pembelian Produk Torabika Duo (Studi Kasus di Area Kabupaten Demak). Journal of Management. Vol. 3, No. 6. (41-56)

Amir, Muhammad dan Ishak, Andi Abdul Razak. 2019. Pengaruh Strategi Promosi Terhadap Keputusan Pembelian Pada Pt. Sumber Alfaria Trijaya Tbk (Alfamart) Makassar. Movere Journal. Vol 1, No. 1. (25-32)

Budiwati, H. (2012). Implementasi Marketing Mix dan Pengaruhnya Terhadap Keputusan Pembelian Konsumen Pada Produk Unggulan Keripik Pisang Agung di Kabupaten Lumajang. Jurnal WIGA, Vol. 2, No. 2, Hal. 29-44.

Dharmmesta, Basu Swastha, Handoko, T. Hani. 2012. Manajemen pemasaran Analisis perilaku konsumen. Edisi Pertama. BPFE, Yogyakarta.

Diyatma, A. J. (2017). Pengaruh Promosi Melalui Media Sosial Instagram Terhadap Keputusan Pembelian Produk Sakaa Bistro \& Bar. eProceeding of Management, Vol.4, No.1, Hal. 175-179.

Fahma Ilmaya (2011) Analisis pengaruh intaraksi harga dan desain produk terhadap keputusan pembelian batik die ka batik Semarang|

hozali. Imam. 2012. Aplikasi Analisis Multivariate Dengan Program IBM SPPSS.

Yogyakarta : Universitas Diponegoro.

Ghozali. Imam. 2005. Aplikasi Analisis Multivariate Dengan Program SPPSS. Semarang : Penerbit UNDIP.

Jogiyanto, 2014. Teori Portopolio dan Analisis Investasi (Edisi ke 10). Yogyakarta. : BPFE.

Lupiyoadi, Hamdani. 2014. Manajemen Pemasaran Jasa. Jakarta. Salemba Empat.

Natalia, P.; Mulyana, M. (2014). Pengaruh Periklanan dan Promosi Penjualan Terhadap Keputusan Pembelian. Jurnal Ilmiah Manajemen, Vol. 2, No. 2, Hal. 119-128.

Malau, Herman. 2017. Manajemen Pemasaran : Teori dan Aplikasi Pemasaran Era Tradisional Sampai Era ModernisasiGlobal. Bandung. ALFABETA.

Seno Adji (2004) melakukan penelitian dengan judul "Pengaruh Harga, Kualitas Produk dan Promosi terhadap Keputusan Pembelian Susu Kemasan Produk PT. Ultrajaya di Salatiga".

Sugiyono. (2000). Metode Penelitian Bisnis. Bandung : ALFABETA. Sugiyono. (2012). 
Masbullah dan Salmi Yuniar Bahri

Memahami Penelitian Kualitatif. Bandung : ALFABETA.

Sugiyono. (2017). Metode Penelitian Kuantitatif, Kualitatif, dan R\&D.. Bandung : ALFABETA, CV.

Sugiyono. (2015). Metode Penelitian Kombinasi Mix Methods).Bandung : ALFABETA.

Sunyoto, Danang, 2014. Dasar-dasar manajeman pemasaran (konsep,strategi, dan kasus).

Yogyakarta: CAPS.

Priyanto, Duwi. 2012. Analisis Laporan Keuangan. PT. Raja Grafindo Persada. Jakarta

Pasaribu, Ruth F. A., Sianipar, Ira Lestari., Siagian, Yona F., dan Sartika, Vier. 2019.

Pengaruh Promosi dan Harga Terhadap Keputusan Pembelian Produk Soyjoy PT. Amerta Indah Otsuka Kota Medan. Jurnal Manajemen. Vol. 5, No. 1. (45-52).

Latief, Abdul. 2018. Analisis Pengaruh Produk, Harga, Lokasi dan Promosi terhadap Minat Beli Konsumen pada Warung Wedang Jahe (Studi Kasus Warung Sido Mampir di Kota Langsa). Jurnal Manajemen Dan Keuangan. Vol.7, No.1. (90-99).

Meleong, L.J. 2011. Metodologi Penelitian Kualitatif Edisi Revisi. Bandung : PT. Remaja Rosdakarya.

Susilo, Heri., Haryono, Andi Tri., dan Mukery, Moh. 2018. Analisis Pengaruh Harga, Kualitas Pelayanan, Promosi, dan Kepercayaan Terhadap Kepuasan Konsumen dengan Keputusan Berkunjung Sebagai Variabel Intervening di Hotel Amanda Hills Bandungan. Journal of Management. Vol. 3, No. 7. (57-83).

Weenas, Jackson R.S. 2013. "Kualitas Produk, Harga, Promosi dan Kualitas Pelayanan Pengaruhnya Terhadap Keputusan Pembelian Spring Bed Comforta”. Jurnal EMBA, Vol 1 No.4. Manado: Universitas Sam Ratulangi Manado 